\title{
The Initial Educational Content of Theatre as a Subject Implemented in 11th or 12 th Grades by Pre-service Theatre Teachers: Relevant and Broad
}

\author{
Vida Kazragytè \\ Vytautas Magnus University, K. Donelaičio g. 58, LT-44248 Kaunas, Lithuania, vida.kazragyte@vdu.lt
}

\begin{abstract}
This article presents the results of an investigation into the initial educational content of theatre subject in 11th or 12th grades in Lithuania. It is shown, that the initial educational content of theatre subject is devoted to obviate the negative pupils' attitudes to themselves and their inabilities to interact. Also, to achieve an expressing pupil's individual point of view, creating respectful relationships, behaving as a co-creator.
\end{abstract}

Keywords: educational content, theatre.

\section{Introduction}

Interest in research in didactics has been growing rapidly in recent years in Europe (Hudson and Meyer, 2011). It is noteworthy that scholars research in didactics understand as "research on teaching and learning in relation to the content and subjects featured in the curriculum" (Ligozat et al., 2015, 313). Nowadays, research in didactics has gained a comparative dimension with the purpose of increasing its synergy. This should help to go beyond the many differences which now exist, e.g. differences between subjects, national contexts, practices occurring in classrooms and didactics as an academic discipline, potentially even escaping beyond the specificity of subjects (Ligozat and Almqvist, 2018). Therefore, research in didactics focuses on broad themes such as teaching traditions and innovations, commonalities and specificities, etc. (Lundqvist et al., 2012). 
In this study, the focus is devoted to the content of theatre as a subject. In most countries, as in Lithuania, in the establishing of theatre as a learning subject the main role was given to the conceptualisation of its educational content through aims and learning outcomes in the curricula. In Lithuania, the educational content of theatre was prescribed firstly in 1996, then in 2008 for the primary and basic education curriculum and in 2011 for the secondary education curriculum. Extant research has identified that the transposition of broadly formulated learning outcomes to the classroom is the biggest challenge for teachers (Højgaard and Sølberg, 2019). As per comparative information across Europe, the aims of the arts (including the art of theatre) curriculum seem to be diverse, wide-ranging and questionable according to real-life classroom accounts (Arts and Cultural Education at school in Europe, 2009).

The selection of more concrete educational content of theatre is left for teachers and textbook writers. However, in more than 20 years not a single textbook for theatre teaching and learning has appeared in Lithuania. The didactics of theatre as the "theory of educational content" (Kansanen and Meri, 1999, 21) in Lithuania is also in its early stages (Kazragyte, 2014). To the best of our knowledge, the situation is not much better in other countries. There are disciplines of theatre didactics taught at universities (for example, Magburg University, Yale University, Vytautas Magnus University), but there is a rather small number of studies, which could partly be included within the didactics of theatre (Keleş and Çepni, 2019; Gray et al., 2018; Jensen and Lazarus, 2014; McCammon et al., 2010).

The research question of this study is as follows: what could be the initial educational content of theatre in grades 11th or 12th? It should be taken into account that theatre is mostly taught in grades 11th or 12th (e.g. in Lithuania), but that pupils reaching these grades have little-to-no experience of learning theatre before.

Indeed, the educational content of theatre is in its early stages, not just teaching and learning processes. It is not yet clear "what is the main body of artistic knowledge and experience that we need in theatre/drama education" (Schonman, 2000, 949). Accordingly, there is a wide diversity of theatre teaching and learning practices, which penetrate into classrooms notwithstanding what is prescribed in the curriculum. In Lithuania and likely other countries, in theatre lessons we can find a kaleidoscope of methods: games and improvisations "for fun", role playing, forum theatre, psychodrama, rhetoric, staging of plays for school events, etc; everything that the written educational theatre content encompasses. It should be acknowledged, however, that the multiplicity of approaches to theatre education, which now prevails, "obscures the common ground they all share" (Martin-Smith, 2005, 3). Moreover, it is important to pay attention to fragmentary, non-conceptualised activities leading to performance skills, without which one could potentially lose "sight of the overall educational and personal journey" during theatre lessons (Duffy, 2016, 38). 
Scholars prompt us to remember that educational content of a subject should be selected according to its value for pupils' education and that is the main mission of didactics (Kansanen and Meri, 1999). Recently, European researchers have attempted to strengthen the ties between educational content and the notion of Bildung (a term used in German, its equivalent in English is formation) (Schneuwly and Vollmer, 2017; Ligozat and Almqvist, 2018). In other words, to underline the power of the content "to form a man as a whole" (Klafki, 2013; cited in Meyer and Rakhkochkine, 2018, 23), namely because the content of knowledge (not activities or experiences in themselves) has the largest impact on the formation of a person.

For Nordembo (2002), the concept of Bildung means both process and product. He asserts that Bildung "does not refer primarily to somebody or something, but to an image - a model - of which somebody or something is to become an image or model" $(2002,341)$. In that formation process, the person is assisting actively. As Nordembo stresses, the rather complex ties between Bildung and educational content are vital. He writes:

"For Bildung the 'content' category is pivotal. The theoretical task is to find a content, that, through its effects on the individual, will lead towards what is 'other'; this will be Bildung. The various Bildungstheorien disagree about what sort of content has value, that is, the ability to elicit Bildung. The approach of Bildungstheorien can, therefore, be said to rest on the fundamental insight that, through appropriation - that is, the learning of something definite, of something with a specific content - we always learn something other to ourselves. This 'something other' must be the touchstone of educational theory and practice. This other is, however, never purely identifiable with the specific content of the curriculum but is rather hidden within those specifics in such a manner that they function as the kind of conduit or servant to Bildung" $(2002,350)$.

Consequently, there is a need to be particularly vigilant of educational content of theatre which emerges not only in the prescribed form (curriculum), but in classroom practices with the purpose of grasping its most vivid and valuable educational characteristics, as in the Bildung process.

This study examines educational content selected and implemented in years 11th or 12th in general education schools by pre-service theatre teachers, who studied theatre and pedagogical preparation concurrently (i.e. theatre pedagogy programme) at Vytautas Magnus University. According to the theatre lessons conducted, pre-service teachers reflectively inquired on the basic gained competencies of a teacher. Such reflective inquiries served as the research material for this study. Pre-service teachers were free to build educational content as "an intersection between content material and education" (Kansanen, 2009, 32). From another angle, pre-service teachers had already studied the didactics of theatre and other pedagogical and psychological subjects and had experience of two pedagogical practices (each lasting approximately two months).

It should be noted that in Immens' (1999) view, every teacher, despite pedagogical preparation, works according to "a tacit theory". In other words, the teacher uses knowledge 
which is rooted deeply in a person's actions, thoughts and values and is not easily visible (Wasonga and Murphy, 2006). The teacher, by reflection or inquiry, can reach "a more explicit theory based on experience" (Immens, 1999 cited in Hultman et al., 2012, 4) and this can give us the appropriate knowledge of educational content and its implementation.

Accordingly, the object of the research is the initial educational content of theatre for 11th or 12th grades, as selected and implemented by the pre-service theatre teachers; our research purpose is to identify the common features of educational content of theatre for 11th or 12th grades. Furthermore, the tasks of the study are described below:

1. To describe the theoretical and practical context of educational theatre content.

2. To characterise the possible initial knowledge, skills, values of the educational theatre content for 11th or 12th grades.

\section{The theoretical context of educational content of theatre}

In this study, educational content of theatre as a subject is understood as a curriculum. The curriculum encompasses aims, learning outcomes and assessments (Motiejūnienè, Žadeikaite, 2009). In detail, the curriculum is described as "what to teach and learn, how to teach and learn, how to evaluate the pupils' progress and achievements, what teaching and learning aids to use" (Republic of Lithuania Law on Education, 4.1.). Learning outcomes are the main part of the curriculum. Since learning outcomes are related to competence development, the curriculum describes three broad learning domains: knowledge, skills and values. In essence, however, all learning domains encompass these concepts and, accordingly, are expressed as knowledge: content knowledge ("I know that"), procedural knowledge (I know "how") and dispositional knowledge ("I know to", i.e. attitudes, moral dispositions, motivation, will and commitment) (UNESCO, What Makes a Quality Curriculum?, 2016, 7). Educational content or a curriculum is in essence a plan of action towards "how well the learners learn" compared with the intended outcomes (Su, 2012, 2).

In teaching and learning practices in Lithuania and seemingly in other countries, three types of educational theatre content are found. Now, let us briefly examine them (the first two are commonly found in non-formal education, but since we are also discussing teaching and learning, educational content also exists (Kansanen, 2011)).

The knowledge of performing a role. In this type of educational content, the aim is to prepare the theatrical performance. Accordingly, the main kind of knowledge, which pupils acquire, is procedural knowledge, namely, knowledge of "how" to perform a role in a performance in front of an audience. Typically, there are two ways to impart pupil-actor knowledge: through (1) memorisation and (2) understanding. If the procedural knowledge is gained mainly through imitation, repetition and memorisation, the knowledge coincides with skills such as "how" to show emotions in a role (Bailin, 2001), and a pupil's performance in a role is relatively unconscious and uncreative. The pupil-actor 
behaves on a stage like an operator. He or she uses habits, i.e., "automated procedures, that are carried out without intellectual effort" (Hudson, 1999, 40). It is also vital that the procedural knowledge, which coincides with performing skills and understanding concepts related to acting in general, cannot be transferred to the next role performance. Accordingly, there is a reasoned opinion that such knowledge is amateur knowledge, appropriate for "one role" in "one performance" only.

Despite this, if the procedural knowledge, understood as skills, is combined with content knowledge, e.g., how to create a role using the Stanislavski method of scenic action, then the performance of a role could be of a high artistic quality. The values fostered in the implementation of that type of educational content are mainly those needed for professional acting (obedience, commitment, discipline). The evaluation of a pupil's achievements occurs publicly during festivals or celebrations and depends on the criteria of audiences or commissions. Mostly, success in front of an audience and experienced pride, as well as dreams about acting, are the main motives for pupils to learn the before mentioned knowledge.

Such educational content of theatre prevails in non-formal education. On the other hand, it is narrow, oriented to the mastery of an actor's job at such an early age, without developing pupils' personality more broadly. Since educational content then has no clear reference point for continuity, one performance follows another, often accidentally or according to teachers' need for self-realisation.

The dramatic experience and considerations. The second type of educational content is broader in comparison with the previous category. Here, pupils are urged to use their knowledge from various fields and life situations in a classroom drama, which the teacher, as a dramatist, leads. Pupils are in the position of actors and spectators, but the last position is considered to be the most important. Subsequently, the pupil-actor performs various kinds of drama activities (role-plays, improvisations, role-on-the-wall, etc.) using theatrical knowledge, i.e. the procedural and content knowledge of a play or improvisation (O'Neill, 2014; Bolton, 1998; Neelands and Goody, 2015). However, the main aim of teaching and learning such educational content is pupils' knowledge, which they achieve through reflection after drama activities and which are accompanied mostly by dramatic experiences. During reflections, pupils consider moral, social and other themes and share various knowledge and understandings that arose in the pretext of the dramatic activities. Such broad content knowledge, which arose in the pupil's mind beyond drama and theatre and is discussed by pupils' and the teacher, does in some way prompt the possible impact of the theatrical performance to the audience, i.e. the capability to transform and develop human consciousness, as is inherent in the art of theatre (Martin-Smith, 2005). Nevertheless, in educational contexts there is a need to have a clear reference point (benchmark) to measure the development of a pupil's consciousness. It is obvious that constructing an instrument to measure the progress of the subject's consciousness is hard. So, instead of this, the assessment of a pupil's achievements in drama 
lessons is related to the drama activity's performance (Jacobs, 2016); this is a challenge depending on the type of educational content aimed for. In addition, the reflections do not always lead to new and valuable understandings. Indeed, pupils often repeat what they already know or come to stereotypical conclusions (Bailin, 1993). This type of educational content of theatre integrates knowledge from many learning subjects and areas, but little attention is paid to procedural knowledge ("how" to perform a role). As such, this is called applied drama or applied theatre. Drama or theatre activities are used as teaching and learning methods, as well as for experiential learning (Vukojević, 2018). On the other hand, drama (theatre) as a learning tool is considered to be a "servant" instead of in its own - "master" - place (Schonmann, 2005), and that has negative consequences. David Honrbrook writes: "I observed many lively drama lessons that were impressive for the range of teaching techniques employed, when the discussion of moral or social issues took precedence over dramatic content these same lessons frequently failed to offer students a broad and balanced experience of the subject" $(2002,13)$.

The education of competence in theatrical form. In contrast to the types of educational content described above, the last is based on the framework of DBAE (Discipline-based Art education), which puts the pupil's learning in an art form at the centre. According to this approach, educational content or theatre curricula are prescribed through learning outcomes in Lithuania and many other countries. The main feature of this type of educational content is its broadness and balance. It encompasses all kinds of knowledge (procedural, content and dispositional) across four foundational disciplines (creation, appreciation, art history and aesthetics). The aim is the development of pupils' competences to create and appreciate the theatre form. The creation should seek not so much to satisfy the needs of spectators, but to foster the creators themselves. Accordingly, pupils are not in positions of actors or reflectors only, but are expected to learn to be young dramatists, actors, stage directors, critics and aesthetics. On the other hand, there are many challenges of the implementation of such an approach. First of all, pupil's theatrical creation depends on the development of his or her mind (Gardner, 1990), and on the person's cultural background and context (Erton, 2018). So, pupil's original theatrical products (roles or etudes) should be evaluated very carefully and using the appropriate criteria. In contrast, professional theatre artists and teachers often assess products according to their own subjective criteria or on the professional mastery alone. Similarly, the objective of devoting more attention to the pupil's knowledge is necessary to appreciate theatrical performances, albeit this is now neglected (Schonmann, 2007) as it is often considered to be unnecessary "theoreticism" and so not taken seriously. Moreover, DBAE is an "approach, it is not a specific curriculum" (Dobbs, 1992, 18). So, to prepare the curriculum of theatre is a big challenge. There is a lack of appropriate knowledge for pupils, because this in some sense should be different from professional knowledge, albeit with some similarities. To date, such "specific content", which could function as "the conduit or servant to Bildung" (Nordembo, 2002, 350), has not been well articulated. 


\section{The research design}

For the research, the thematic analysis strategy was applied. Thematic analysis is a qualitative, inductive analysis, which produces conclusions about themes in recorded messages (i.e., in the texts) (Neuendorf, 2019; Žydžiunaite and Sabaliauskas, 2017). The thematic analysis of the reflective inquiries $(\mathrm{N}-18)$, performed by pre-service theatre teachers studying a theatre pedagogy programme (bachelor) at Vytautas Magnus University, was conducted. The reflective inquiries (every inquiry totalled approximately 15000 words in scope) were prepared according to the theatre lessons conducted (in all no fewer than 36) during teaching practice (each with a duration of roughly two months) in grades 11th or 12th of general education schools in 2018 and 2019.

The purpose of the thematic analysis was to identify the commonalities in the themes of initial educational content that was selected and implemented by pre-service theatre teachers. The thematic analysis was conducted after the models of educational theatre content were prescribed and the main themes identified. The qualitative analysis was performed according to the recommendations of Neuendorf (2019) using four stages: 1) during reading, the reflective inquiries recognised phrases according to a priori known themes, i.e. how educational content was selected and implemented (what was taught, how this was taught, how the achievements were assessed), were separated (N-216), along with other phrases crucial to teaching and learning; 2 ) in those themes, the phrases (N-216) were structured according to commonalities with the purpose of identifying a saturated set of themes; 3 ) we developed a detailed analysis of the commonalities in each saturated theme (especially the theme "expression of educational content through learning outcomes"); and 4) at the end of the analysis, the most salient constellations of the themes were defined and named. These all connected to the "story" (Neuendorf, 2019, 213) of how the initial educational content of theatre was selected, implemented and assessed. These themes are outcomes, which are presented below with a process-based model. The analytical text, data segments and analysis of the extant literature are investigated. The phrases from our reflective inquiries are presented as illustrations and enclosed in quotation marks and italics (the language has not been improved).

\section{Results}

Focus - on the real difficulties that pupils face in classrooms. The research showed that all (N-18) pre-service theatre teachers attempted to get to know the pupils and select educational content of theatre according to their needs, or, in their own words, "difficulties" or "problems". The teachers observed the pupils, tried to feel and understand their thoughts and feelings, talked to them in a group and individually ("I gave them broad questions to know the expectations about theatre lessons") and used their 
feedback. If teachers felt their pedagogical interaction with pupils during lessons was weak, they organised surveys or discussions after which they adopted lesson plans more comprehensively ("After analysis of the survey I decided to pay more attention for pupils' needs, not myself").

Teachers identified the difficulties in pupils' inner state and communication abilities ("I noticed a particularly serious problem - pupils are less and less in touch with each other, fleeing from themselves, putting on various masks to be invulnerable. And being in a mask hurt others"). Teachers also discerned that a large number of pupils "do not believe they can be interesting to anyone" and have impassive or superficial attitudes towards arts' lessons ("Just to sit down will be enough", "Theatre lessons are for entertainment"). Similarly, part of pupils' attitudes to themselves and others are stressful ("they are full of fears"). Pupils lack skills to handle their own emotions and to interact with others ("There was no trust, no support for the ideas of other", "there was no interconnection, the alienation prevailed"). Teachers noted that some mentors take theatre lessons without paying attention to these and other difficulties ("There is a talk about pupil's problems, but no help them in theatre lessons"). Consequently, pre-service theatre teachers "did not simply choose what has been done before by others or what will be "easy" (McNally, 2010, 8), but tried to invent content truly relevant to pupils".

\section{Educational content through three main learning outcomes}

According to this study, in their first theatre lessons pre-service theatre teachers decided to nurture pupils' 'opposite', i.e. good qualities. In other words, they selected educational content that nurtured the desirable qualities instead of the noticed limitations and obstacles in pupils' behaviour. They selected and implemented educational theatre content that could be expressed through no fewer than three main learning outcomes, which were set up during the process (see Fig. 1).

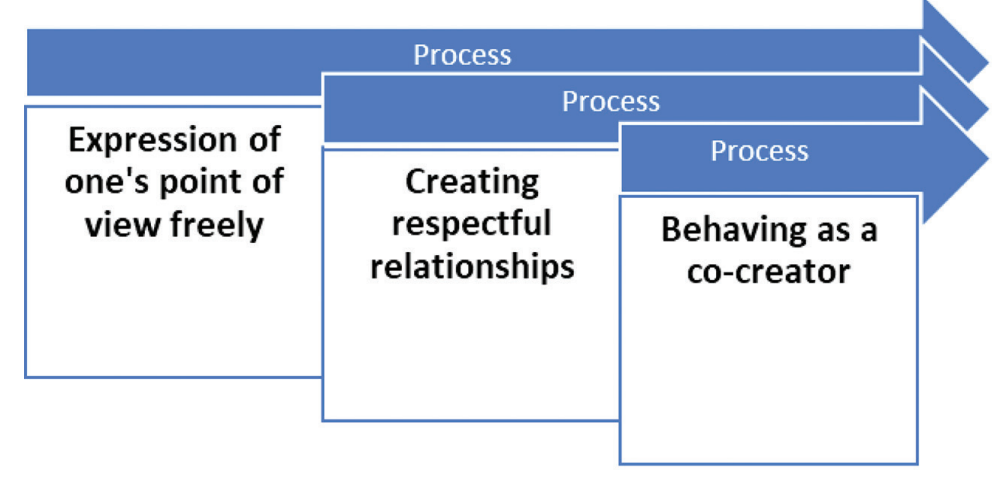

Figure 1. The initial educational content of theatre, selected for pupils in grades 11th or 12th

The development of these outcomes (abilities) was accompanied by experiences and rather broad knowledge joining together many education areas; this knowledge in general could be named cultural knowledge. The consistency in the development of these abilities, 
the details of the educational content and several interlinks with cultural knowledge will be explained in the following section.

\section{What was taught and learned, and how?}

Firstly, teachers were of the opinion that pupils could express their own point of view freely. This was largely taught and learned indirectly and non-verbally through theatrical games, drama methods, improvisations, sharing opinions on relevant themes, including difficulties at school, theatrical performances, violence, alcohol, etc. Teachers sought pupils to share their opinions openly ("Express an opinion different from that of the majority in a group"). Because those activities required spontaneous actions, this was a big challenge for pupils. Most of them felt unsafe, were afraid to perform the tasks due to all of the possible mistakes or used crude expressions ("Pupils relied only on themselves; they wished to appear in front of the class as the coolest"). Teachers used jokes and absurd situations, which allowed pupils to "forget" about protecting themselves from others, as well as invented methods to strengthen natural and good behaviour; pupils applauded each other for making mistakes and gave compliments for "small" creative achievements, such as "simply being different" (Cropley, 1999, 512). They also broke through stereotypical behaviour in pupils and helped them to reveal their true feelings, thoughts and attitudes. The expressions these activities served as a mirror where pupils could see who they are and to get to know themselves better. Teachers mentioned: "Pupils need to recognise their weaknesses and strengths as human beings, without underestimating and exaggerating themselves"; "I aimed so that everyone can consciously recognise his or her role, freedoms and responsibilities, and resolve conflicts". Despite this, it seems that the main method was the teacher's attentive listening, observation and accepting all pupils equally and their various behaviours and expressions gently without judgement: "I tried to understand pupils, not just focused on activities, tasks"; "My simple and human communication allowed the pupils to express their own opinions, make rational suggestions".

The teachers argued about why they decided to start with such educational content and referred to the development of social and creative competencies, but were only partially aware of their contribution to the development of theatre competence (for teaching and learning to create and appreciate theatre). Hence, it could be said that teachers aimed for every pupil to listen to his or her inner self ("Pupils chatted and, I believe, deeply communicated with themselves"). To create a theatre form (role or etude), a pupil as a creator first of all should learn to speak and act according to their inner "voice" and truth, according to Stanislavski (1963), and to express the subjective world freely. Moreover, the pupil should learn to use their feelings in the expression of theatre and during its appreciation. Without feelings, the true relationships between means of expression in art's creation cannot be taught (Reimer, 1992). It is important to add that, according to research, pupils do not understand such aims nor the appropriate theatrical and cultural knowledge. Pupils interpreted such educational content as teachers' caring for them sincerely ("Pupils understood that I am a human, who cares about how pupils feel"). 
The second element of educational content and learning outcome was teaching and learning to create respectful relationships between pupils and maintain their trust in a teacher. The research showed that teachers were not satisfied by just increasing group coherence using physical means, rules and discipline-based games and various educational activities, including meditation. They talked to pupils about respect as an essential feature of good relationships and favourable learning environments ("I emphasised the importance of respecting the other, accordingly, I had to restrict the pupils' freedom to speak as much as they wanted and what they wanted"). On the other hand, teachers did not appoint great significance to their words. They struck "a balance between being friendly and exacting teacher", used indirect methods to motivate pupils to pay attention to their own behaviour and to urge them appreciate it according to general rules ("I myself involved in a game to show that everyone follows the same rules"). Teachers told stories with metaphorical hints, sometimes paused when talking, left class for a moment or began to play the piano, sending the message that they as humans need respect ("The relationship should be defined very clearly - there should be a respect"). Indirect and/or non-verbal ways are required for pupils to feel and think inside, according to their individual self (prolonging the process of the achievements of the first outcome).

Almost all teachers mentioned the real dramatic situations in which the dispositional knowledge about the respectfulness and trust in a teacher were conveyed. One teacher argued that once she did not agree with the disrespect she received from one pupil and did not allow her to return to the class. Such firm behaviour gave good results: "The rest of the lesson was full of vitality. Pupils trusted me that I am able to make bold decisions for the better. The girl apologised, admitted her guilt. She changed her relationship with herself and her behaviour. The respect should be expressed for all class". It is obvious that such situations are highly dramatic and differ from those dramatic situations used to create classroom drama. The latter occurs in "as-if" (playful) situations and with imagined personages (Bolton, 1998). In the former, the conflict and its resolution were real and served first of all to check whether the teacher believed in the knowledge that he or she proclaimed. Of course, pupils often hear about respectful relationships, but are not convinced of their necessity, comfortable with their expression or, most likely, do not know how to express such a relationship. In the aforementioned situation, the teacher performed the role of the reliable teacher. Accordingly, the girl created her own role as well, revealing the ability to create respectful relationships (after a conflict). It should be added that respectfulness is one of the most important dispositional understandings. When the pupil is capable of expressing respectfulness, that means at the same time that the expression of a view (relation) is done consciously, i.e. according to the point of the "other". The capability to take into account the view of the "other" is central in social interactions (Mead, 2005) and in cultural education in general (Davis and Gardner, 1992). Similarly, such situations call upon the thought that dispositional knowledge 
(respect and other ethical values) comprise important theatrical content, which should be comprehensively demonstrated and experienced, not just talked about.

According to the research, the third learning outcome sought was the pupil's ability to behave as a co-creator. In the research literature, co-creation is known as a drama teacher's co-creation (McDonagh and Finneran, 2017). In the study, the pre-service teachers pursued pupils as co-creators, i.e. to be able to collaborate with the other; the author of an article, pictures, story or novel (e.g. Albert Camus "Stranger") or the unknown author of a language or civics education subjects, etc. In co-creation, pupils were urged to take into account creative products made by "others" and to saturate the various types of knowledge (content, procedural, dispositional) in a complex way.

Pre-service teachers were aware of how to construct tasks appropriate for pupils to behave as co-creators and the educational impact of the co-creation process (" $\mathrm{A} \mathrm{co}$ creation is useful, when the teacher offers for pupils only the basic terms of the assignment"; "Pupils experienced a strong sense of community, when they behave as co-creators"). The teachers "dosed" the breadth of the creativity by first giving broad tasks in groups, before awarding more narrow, individual tasks. For example, firstly, teachers assigned pupils tasks to express their own attitude, according to the author's ideas (e.g. discussing what it means to be a citizen), or to work in a small group to create a short movie based on the inspirations of an author and observing the environment. Thereafter, the tasks were more narrow and complex: to create an etude by changing the place in a novel or according to a freely chosen set of pictures, etc. Sometimes teachers assumed the role of a co-creator too and performed a task in the pupils' creation. The pupils-audiences also behaved as co-creators. They analysed each other's creations by doing creative tasks (e.g. identifying the tasks of the personages). Only when teachers noticed a lack of performing skills (e.g. in the concentration of attention or public speaking) would separate knowledge and specific training be provided. The distance between skills trained and their use in a task was very short.

In light of this, it could be said that the co-creation in some way could be equated to an apprenticeship. Pupils learned knowledge by imitating the other's creative product. The apprenticeship is one of the oldest ways to prepare young actors (Stanislavski, 1963). Furthermore, pupils behaving as co-creators simultaneously developed their abilities to hear, see, reason, react in a role and create logical changes (events) according to the appeared meanings, etc., which are basic elements in the creation of theatre, as well as learning other subjects. Moreover, pupils learning to be co-creators learnt to appreciate what is created by another and eventually reached a balance between the main two artistic abilities: expression and appreciation (Smith, 1992).

\section{How were learning achievements assessed?}

The research showed that the pre-service teachers defined the criteria for the assessment of pupils' achievement, but in essence, the main method of assessment coincided with the public recognition of real changes in pupils' behaviour in comparison to their 
previous difficulties. For example, performing a task multiple times was identified as an achievement ("Pupils did not refuse to do on the assignment and were involved"), as well as the facts of the "voluntary assistance" also being recognised as an achievement. To make that achievement explicit, teachers mostly used the reflections of pupils at the end of lessons, giving broad questions ("What did we achieve?", "How are you?"). Teachers and pupils noticed the achievements as "clear without words" and given in a rather generalised way: "We were involved" or "The whole process was alive with lots of laughter. All 100 percent of pupils were co-creators". The achievements coincided with various good features in pupils' behaviour, observed by teachers and pupils and expressed in a rather free style of talking: "Little-before-communicated pupils became a team", "No one felt rejected, no one created an uneven or pessimistic atmosphere", "Pupils disciplined each other". As such, achievements were reached in a live and fresh experience in classrooms, their assessment became more strictly defined criteria which could seem formal (Andrade et al, 2014). It is necessary to note that teachers aimed for pupils to assume the responsibility of demonstrating those achievements in subsequent lessons; therefore, at the end of lessons pupils were reminded about rules, respectful relationships and being a co-creator, etc.

\section{Conclusions}

It seems reasonable to suppose that the initial educational content of theatre as a subject in 11th or 12th grades should be selected with a clear relation to the difficulties which pupils readily face (first of all, the domination of negative pupils' attitudes to themselves and their inabilities to interact). Teachers' real concerns allows pupils to grasp the content according to its real value in their education.

The results of this study suggest that the initial educational content of theatre consists of no fewer than three learning outcomes (to express an individual point of view freely, to create respectful relationships and to behave as a co-creator). The logical consequence in the learning outcomes could be envisaged: at the beginning, the pupil should be able to freely express themselves, then to do that whilst taking into account the "other" and, finally, to collaborate with the "other". The knowledge leading to those learning outcomes is purely theatrical, but not so much according to scenic production; however, it is related to changes in the pupil's inner world and habits. It seems that the educational content of theatre in the initial phase of teaching and learning is not tied to discrete theatrical knowledge only, but belongs to initial broad cultural education.

The most crucial features of the implementation of such educational content are indirectness, emphasis on respect (and other ethical values) and teachers' moral behaviour in conflicting situations. The first steps of teaching and learning in theatre occur more by doing (experiential learning) than straight and open orientation towards explicit learning outcomes (it is important that those learning outcomes which were achieved 
by the pupils in the study were not presented to them clearly at the start of the learning process). On the other hand, the intended learning outcomes were understood quickly by pupils and supported throughout their achievement, similarly to the Bildung process. In addition, the evaluation of pupils' achievements of theatre occurs more through the observation and recognition of real positive changes in their behaviour than according to the progress in their verbal knowledge development. The attention of teachers to the real changes in pupils' behaviour could also be interpreted as successful attempts to grasp the "specifics" of content that allowed the pupils "to learn something other [than] ourselves", i.e. implements Bildung. To more fully understand the ties between the initial educational content of theatre and Bildung, however, further studies are needed.

In light of this, it should be acknowledged that the learning outcomes, selected to be achieved in the first steps of learning and teaching in theatre, are understood more implicitly than explicitly (they are not mentioned in theatre curricula in Lithuania or, if they are, they are explained poorly). So, there is a need to broaden the 'lens' towards the construction of theatre curriculum, as well as its re-construction. The educational content of theatre as a subject should help pupils to learn to behave according to their individual selves and to experience the significance of various relations and values by becoming a co-creator, as well as to gain broad cultural and artistic knowledge (e.g. by taking into account the other, creating and perceiving, etc.). Such educational content could be named as initial broad cultural education content, because it lies on the boundaries between theatre, sociology, aesthetic and other cultural studies, including religion studies. The main issues are the articulation of such broad knowledge and showing their reasonable ties with theatre art.

\section{References}

Andrade, H., Hefferen, J., \& Palma, M. (2014). Formative Assessment in the Visual Arts. Art Education Journal, 67(1), 34-40.

Arts and Cultural Education at school in Europe. (2009). Education, Audiovisual \& Culture Executive Agency of the European union - European Commission. Retrieved from http:// eacea.ec.europa.eu/education/eurydice/documents/thematic_reports/113en.pdf

Bailin, Sh. (1993). Drama as Experience: the Critical View. Canadian Journal of Education, 8(2), 95-105.

Bailin, Sh. (2001). In the Spaces Between the Words: Play Production as an Interpretative Enterprise. Journal of Aesthetic Education, 35(2), 67-75.

Bolton, G. (1998). Acting in Classroom Drama: a Critical Analysis. Great Britain: Henry Ling Limited, Dorset.

Cropley, A. J. (1999). Definitions of Creativity. In: M. Runco, St. R. Pritzker (ed.). Encyclopedia of Creativity. California: Academic Press, Vol. 1, 511-524. 
Davis, J., Gardner, H. (1992). The Cognitive Revolution: a Consequences for the Understanding and Education of the Child as Artist. In B. Reimer, R. A. Smith (Eds.). The Arts, Education and Aesthetic Knowing. (Part II, pp. 92-123). Chicago, USA: The University of Chicago Press.

Dobbs, S. M. (1992). The D.B.A.E. Handbook: An Overview of Discipline-based Art Education. Santa Monica: Getty Trust.

Duffy, P. (2016). Theatre Curriculum in the US: a Great Tasting Sandwich on a Stale Bread. Research in Drama Education: The Journal of Applied Theatre and Performance, 21(1), 37-41.

Erton, I. (2018). The Essence of Semiotics as a Mediator of Communication and Cognition. International Online Journal of Education and Teaching (IOJET), 5(2), 267-277. Retrieved from http://iojet.org/index.php/IOJET/article/view/351/234 (Accessed 28 August 2019).

Gardner, H. (1990). Art Education and Human Development. California, Los Angeles: the Getty Education for the Arts.

Gray, C., Pascoe, R., Wright, P. (2018). “I Felt That I Could Be Whatever I Wanted”: Pre-service Drama Teachers' Prior Experiences and Beliefs About Teaching Drama. International Journal of Education \& the Arts, 19(10). Retrieved from https://doi.org/10.18113/P8ijea1910 (Accessed 28 August 2019).

Guijarro, B. (2018). Drama as a Social and Educational Tool in a Challenging Context: Analysis of a Experience, The International Journal of Pedagogy and Curriculum, 25(4), 17-31.

Højgaard, T., Sølberg, J. (2019). Competencies and Curricula: Two Case Stories of Two-dimensional Curriculum Development. European Journal of Science and Mathematics Education, 7(1), 50-60.

Hornbrook, D. (2002). Drama and Education. In On the Subject of drama, Routledge, 6-17.

Hudson, H. (1999). Seeking Connections between Different Perspectives on Teacher Education: in Support of a Science of the Teaching Profession. In Fr. Buchbergen, P. Kansanen (ed.). Didaktik / Fachdidaktik as Science (-s) of the Teaching Profession (p. 37-47). Thematic Network of Teacher Education in Europe (TNTEE Publications), 2(1).

Hudson, B., Meyer, M. A. (eds) (2011). Beyond Fragmentation: Didactics, Learning and Teaching in Europe. Opladen and Farmington Hills, MI: Barbara Budrich Publishers.

Hultman, G., Löfgren, R., Schoultz, J. (2012). Subject Didactics in Practice - Hidden in the Process. Education Inquiry, 3(1), 3-18.

Jacobs, R. (2016). Challenges of Drama Performance Assessment. Drama Research: International Journal of Drama in Education, 7(1), 1-18.

Jensen, A., Lazarus, J. (2014). Theatre Teacher Beliefs About Quality Practice in the Secondary Theatre Classroom: An Ethnographic Study. Youth Theatre Journal, 28(1), 44-60.

Kansanen, P., Meri, M. (1999). The Didaktik Relation in the Teaching - Studying - Learning Process. In Fr. Buchbergen, P. Kansanen (ed.). Didaktik / Fachdidaktik as Science (-s) of the Teaching Profession (p. 107-116). Thematic Network of Teacher Education in Europe (TNTEE Publications), 2(1).

Kansanen, P. (2009). Subject-matter Didactics as a Central Knowledge Base for Teachers, or Should it be Called Pedagogical Content Knowledge? Pedagogy, Culture \& Society, 17(1), 29-39. 
Kansanen, P. (2011). The Curious Affair of Pedagogical Content Knowledge. In B. Hudson \& M.A. Meyer (Eds.), Beyond Fragmentation: Didactics, Learning and Teaching in Europe (pp. 77-90). Opladen \& Farmington Hills, MI: Barbara Budrich Publishers.

Kazragytè, V. (2014). Lietuvos mokyklinė teatro didaktika: paradigmų priešpriešos ir sąveika. Iš Ugdymo paradigmu iššūkiai didaktikai. Kolektyvinè monografija [sudarè Ramutè Bruzgelevičienè] (329-361). Vilnius: Lietuvos edukologijos universiteto leidykla.

Keleş, P., Çepni, P. (2019). Evaluating Drama Activities on Fifth Grade Science Subjects with the Developed Analytical Rubric. Universal Journal of Educational Research, 7(2), 328-336.

Ligozat., F., Amade-Escot, C., Östman, L. (2015). Beyond Subject Specific Approaches of Teaching and Learning: Comparative Didactics [Editorial]. Interchange 46(4), 313-321.

Ligozat, F., Almqvist, J. (2018). Conceptual Frameworks in Didactics - Learning and Teaching: Trends, Evolutions and Comparative Challenges, European Educational Research Journal, 17(1), 3-16.

Lundqvist, E., Almqvist, J., Östman, L. (2012). Institutional Traditions in Teachers' Manners of Teaching, Cultural Studies of Science Education, 7(1), 111-127.

Martin-Smith, A. (2005). Setting the Stage for a Dialogue: Aesthetics in Drama and Theatre Education. Journal of Aesthetic Education, 39(4), 3-11.

Mead, Cr. H. (2005). The Internet Encyclopedia of Philosophy. Retrieved from http://www.iep. utm.edu $/ \mathrm{m} / \mathrm{mead} . h \mathrm{tm}$

Meyer, M., A., Rakhkochkine, A. (2018). Wolfgang Klafki's concept of 'Didaktik' and its Reception in Russia, European Educational Research Journal, 17(1), 17-36.

McCammon, L. A., O`Farrell, L., Saebo, A. B., Heap, B. (2010). Connecting With Their Inner Beings: An International Survey of Drama/Theatre Teachers' Perceptions of Creative Teaching and Teaching for Creative Achievement. Youth Theatre Journal, 24, 140-159.

McDonagh, F., Finneran, M. (2017). The Teacher as Co-creator of Drama: A Phenomenological Study of the Experiences and Reflections of Irish Primary School Teachers. Irish Educational Studies, 36(2), 169-183.

McNally, G. (2010). Developing the Socially Responsible Theatre Teacher. Incite / Insight, 1(6), 8-9.

Motiejūnienè, E., Žadeikaitė, L. (2009). Kompetencijų ugdymas: iššūkiai ir galimybès. Pedagogika: mokslo darbai, 95, 86-93.

Neelands, J., Goode, T. (2015). Structuring Drama Work. Cambridge University Press.

Neuendorf, K. A. (2019). Content Analysis and Thematic Analysis. In P. Brough (Ed.), Research Methods for Applied Psychologists: Design, Analysis and Reporting (pp. 211-223). New York: Routledge.

Nordenbo, S. E. (2002). Bildung and the Thinking of Bildung. Journal of Philosophy of Education, 36(3), 341-352.

O'Neill, C. (ed.) (2014). Dorothy Heathcote on Education and Drama: Essential Writings: London: Routledge. 
Reimer B. (1992). What Knowledge is of Most Worth in the Arts? In the Arts, Education and Aesthetic Knowing. Part II, ed. B. Reimer and R. A.Smith. - Chicago: The University of Chicago Press, 20-51.

Republic of Lithuania Law on Education (As last amended on 22 December 2015 - No XII-2213).

Schneuwly, B., Vollmer, H. J. (2017). Bildung and Subject Didactics: Exploring a Classical Concept for Building New Insights. European Educational Reserach Journal, 17, I, 37-50.

Schonmann, Sh. (2000). Theatre and Drama Education. In: B. Moon, M. Ben - Peretz, \& S. Brown, Routledge International Companion to Education (pp. 944-955). London and New York: Routledge, Taylor and Francis Group.

Schonmann, Sh. (2005). „Master“ versus „Servant“: Contradictions in Drama and Theatre education. Journal of Aesthetic Education, 39, 4, 31-39.

Schonmann, Sh. (2007). Appreciation: the weakest link in Drama / Theatre Education. In International Handbook of Research in Arts Education, L. Bresler (ed.) (pp. 587-599). Part 1, Springer.

Schonmann, Sh. (2009). The Game Veteran Theatre Teachers are Playing: Anatomy of Musings. Teachers and Teaching: Theory and Practice, 15, 515-538.

Smith, R. A. (1992). Toward Percipience: a Humanities Curriculum for Arts Education. In: B. Reimer and R. A. Smith (ed.), The Arts, Education and Aesthetic Knowing. Part II (pp. 51-69). Chicago: The University of Chicago Press, 1992.

Stanislavski, C. (1963). An Actor's Handbook. New York: Theatre Arts.

$\mathrm{Su}$, Sh.-W. (2012). The Various Concepts of Curriculum and the Factors Involved in Curriculamaking. Journal of Language Teaching and Research, 3(1), 153-158.

UNESCO International Bureau of Education. What Makes a Quality Curriculum? (2016). Retrieved from https://unesdoc.unesco.org/ark:/48223/pf0000243975 (Accessed 26 August 2019).

Vukojević, Z. (2018). Opinions of Future Primary Education Teachers on the Application of Drama in Education (DiE). Croatian Journal of Education, 20(2), 107-130.

Wasonga, T. A., Murphy, J. F. (2006) Learning from tacit knowledge: the impact of the internship. International Journal of Educational Management, 20(2), 153-163.

Žydžiūnaitè, V., Sabaliauskas, S. (2017). Kokybiniai tyrimai. Principai ir metodai. Vilnius: Vaga. 


\title{
Pradinis teatro dalyko ugdymo turinys, igyvendinamas būsimụjų teatro pedagogụ 11 arba 12 klasèse: aktualus ir platus
}

\author{
Vida Kazragyte்
}

Vytauto Didžiojo Universitetas, K. Donelaičio g. 58, 44248 Kaunas, Lietuva, vida.kazragyte@vdu.lt

\section{Santrauka}

Šiuo metu iggvendinamas teatro ugdymo turinys yra kelių tipų: (1) orientuotas į vaidmens igūdžių atlikimą; (2) draminius išgyvenimus ir apmąstymus; (3) teatro formos mokymą(si). Pastarajam tipui atstovauja teatro dalyko bendrosios programos $(2008,2011)$. Tyrimo klausimas buvo toks: koks galètų būti pradinis teatro dalyko ugdymo turinys 11 arba 12 klasėse, atsižvelgiant ¡̇ tai, kad teatro dalyko mokymas Lietuvoje kol kas neturi tęstinumo, nors programos parengtos taip, tarsi toks tęstinumas egzistuotų.

Straipsnis pateikia tyrimo, atlikto taikant tematinès analizės strategiją, rezultatus. Buvo išanalizuota 18 būsimųjų teatro mokytojų refleksyviųjų tyrimų tekstų, parengtų pedagoginès praktikos metu 11 arba 12 klasėse. Tyrimas parodè, kad būsimieji teatro mokytojai, vesdami teatro pamokas, stengesi suprasti realius sunkumus, su kuriais mokiniai susiduria, ir pagal tai apibréžti teatro mokymosi pasiekimus. Nustatyta, kad mokytojai siekẻ ne mažiau kaip trijų mokymosi pasiekimų (gebẻjimų): reikšti savo požiūrị, kurti pagarbius santykius ir elgtis kaip bendrakūrẻjai. Šių mokymosi pasiekimų nuoseklumas yra pagrịstas: pradžioje mokiniai mokosi atverti savo „ašc, po to tai daryti atsižvelgdami $\mathfrak{j}$ „kitą“, o dar vèliau - kurti bendradarbiaudami su „kitu“. Kita vertus, tai teatriniai pasiekimai, kurie gali būti įvardijami kaip pradiniai plataus kultūrinio ugdymo pasiekimai.

Esminiai žodžiai: ugdymo turinys, teatras.

Gauta 20190831 / Received 31082019

Priimta 20200128 / Accepted 28012020 